DOI: https://doi.org/10.3126/tgb.v6i0.26162

\title{
Review of vedic Literature from the Perspective of Physical and Human Geography
}

\section{Bishal Gnyawali1}

\begin{abstract}
Vedas are earliest collection of Hindu scripture. The word Veda was originated from Sanskrit verb 'Vida' inane meaning to "to know". Vedas are collection of knowledge. Literatures, written on the basis of Vedas are called Vedic literature. Itihansas and puranas are also known as Vedic literature. Each and every dimension of geography is expressed in Vedic Literature very strongly. This paper simply tries to present the geographical issue expressed in different Vedic literature. Different research papers written about Vedic geography, books of Vedas and puranas are used as materials for the formation of this paper. Topographic explanation and their classification for regionalization is carefully presented in vedic literature such as Dwipas, Khandas and Barshas. River is praised as mother in Vedas and nature and behavior of river was known by Vedic people. Ricveda is full of praising river. Seasonality month and different weather is explained in different Vedas and vedic literatures. Six seasons and twelve months are explained in vedic literature. Fire, wind, water, earth are taken as different forms of god and praised as human environment interaction. People are discouraged for deforestation means not to destroy home of god. Quantitative and mathematical geography is another great feature of vedic literature. Measurement unit techniques of time and distance are very strong geographical representation of vedic literature. The measurement of time starts from 'pramanu' to 'mahayuga' and distance starts from 'pramanu' to 'krosha'.
\end{abstract}

Key words: Ved, Vedic, Purans, seasons, measurement, geography

\section{Introduction}

Geography is a discipline devoted to study relationship between human and environment with reference to its location. It is taken as bridge between physical science and social science. It is also known as mother of science as all branches of science are originated from geography. It is oldest discipline among various disciplines as father of geography Eratosthenes first used the word 'geography' for study of earth in second century BC (Roller, 2010). Geography has passed various paradigms and ultimately reached the paradigm of science and technology which

1 Central Department of Geography, Tribhuvan University. Corresponding e-mail: bishalg853@gmail.com 
was originated as subject to describe the earth surface. Geographical ideas and knowledge are expressed in Vedic literature in different form. Directly or indirectly, geographical ideas are shared in Vedic and Pauranic literature. Different dimension of geography like geomorphology, climatology, human settlement, livelihood etc. are studied in Vedic literature.

Vedas are earliest literature of universe meaning to knowledge. The word Veda is rooted from the Sanskrit verb 'vid' which means 'to know'. Veda explains origin of universe, origin of earth, livelihood strategies of human in Vedic period human adaptation to environmental situation, use of science and technology and so on. Vedas are earliest literature of universe meaning to knowledge. The word Veda is rooted from the Sanskrit verb 'vid' 'Jnane' which means 'to know'. Veda explains origin of universe, origin of earth, livelihood strategies of human in Vedic period human adaptation to environmental situation, use of science and technology and so on. The time of Veda is confined more than three lakh years before today (Dinanath Shastree). It is believed that Veda was originated from mouth of Brahma then moved through hearing and memorizing system (Sruti and Smriti). Brahma told Veda to Nerada told to Veda Vyasa (Krishna Dwaipayana) who codified Veda in graphic form. Veda Vyasa, grandfather of Kauravas divided a single Ved into four branches by name "Ricveda Yajurveda, Samaveda and Atharveda". Each Veda consists of four parts- the Samhitas (hymns), the Brahmanas (rituals), the Aranyakas (theology), and Upanisadas (Philosophy). The collection of hymns or mantras is called samhita. Brasmanas are ritualistic text and include percepts and ritualistic duties. The Upanishadas are the concluding and philosophical part of Vedas and therefore called Vedanta. The Aranyakas and Upanishadas are the concluding portion of Brahmanas which discuss the philosophic problems. Besides this Maharshi Veda Vyasa composed an epic Mahabharat as fifth Ved (Pancham Ved) greatest of the world in volume with one hundred thousand stanzas. He Wrote 18 great Puranas as Panchamved (Bhagvat. 1:4: 20). It means Puranas are also extracted from different Veda knowledge extracted from Veda may be extracted from Puranas also. Therefore, Ppuranas are also as important as Vedas are important.

\section{Methodology}

The paper is based on secondary information. Available relevant papers are reviewed to prepare the paper. Materials taken from internet are also included here. Original text of different Puranas is also taken as review material. 


\section{Result and discussion}

\section{Topographic explanation}

Topographic description is silently rooted in all of the Vedas and puranas. Every event and phenomena discussed in Puranas are occurred in certain topographical feature. In Puranas, significance of different topographical features is described by many perspectives. Earth is divided into seven continents (Sapta dwipas) namely Jambu, Plaksha, Salmali, Kusha, Krauncha ,Shaka and Puskara (Bhadwat, 5:16:2). Every Dwipas are rounded by oceans called saptasagaras. Among seven, the Jambu Dwipa is taken as holy and largest dwip. Jambu Dwipa is also divided into nine Barshas namely; Ramyak, Kuru, Hari, Bharat, Ilabrita, Kimpurusha, Ketumal, Hiranyama and Uttarkurubarsha. Every barsha is divided into many Khanda e.g. Bharat Barsha has Ilabrata, Rewa Bharat and Himawat Khanda (Bhagvat 5:16). Nepal is within Himavat Khanda. These Khandas are overlapping with each other according to their properties, for example Bharat Khanda and Himavat Khanda are overlapping. Bharat Khanda is named in terms of kingdom of great king Bharat and Himavat Khanda is named in terms of Himalayan mountain. In each Barsha so many mountains are there. The major mountains of Bharatbarsha are Malaya Mangalaprastha, Mainaka, Trikuts, Rishabha, Kutak, Kollaka, Sahya, Devagiri, Rishyamook, Shreeshaila, Benkata, Mahendra, Waridhara, Windhy, Shaktiman, Rikshagiri, Pariyatra, Drona, Chitrakuta, Gavardhana, Raivataka, Kukubha, Nila, Gokamokha, Indrakila and Kamagiri (Bhagvat, $5: 18)$.

\section{Seasonality, months weather and climatic analysis in Vedas}

Seasonality and months are also explained in Vedic literature. In Rig Veda six seasons and twelve months concept have been analyzed. Vedic Saints (Rishis) were conscious about winter solstice and related the advent of rainy season, for instance 'Indra opens the water content from south and that will be fallen over sea' (Luitel b, 2066). Regarding the seasons, Ved-Vyasa was concussing and he grouped months as one set of chronological seasons like," Jaistha and Ashar are 'Grishma' or summer related season" (Luitel, 2066a). '... Shrawan and Bhadra are 'Barsha' or rainy related season' (Luitel, 2066a). 'Ashwin and Kartik are Sarat or autumnal related season, (Luitel, 2066a). Marga and Pausha are 'Hemant' or winter like season. 'Magha and Falguna are Shisir or winter season' (Luitel, 2066a). Similarly, Chaitra and Baishakha are basant or spring season. The time of newyear is situated during spring season during which seasonal newness use to be seen everywhere including vegetation and climate. A year is classified into two "Ayans", an ayan is full of three season 'Ritus' similarly a Ritu is full of two months. Thundering and lightening concept 
was dealt in Veda (Luitel, 2066a). The relation between winter and paddy thresh was analyzed here (Luitel, 2066a). So, the weather knowledge of Vedic farmer was very scientific. The cause of rainfall is sun and this cause was first realized by Vedic people. 'The sun shine partly divided the wealth of Indra (rain) on land' (Luitel, 2066a).

\section{River}

River is another important feature of Vedic literature. Vaidic civilization emerged is river basin named Indus Valley. Hermits of Vedic age used to choose place of river beach for their meditation. They used to collect record of flooding time and duration of floods in rivers. Hermits of Vaidic age are taken as fluvial geographer because they had idea of flooding nature of rivers and associated landforms. They had taken water as Barundev and river as mother. They always worshipped river and water before using it. All the chapters in Ricveda are full of praises over river referred to as 'Sarasvati'. It is described as 'Glorious, loudly roaring", "Strongly Flooding" (Luitel, 2066b); "mighty river with great floods", "most powerful among rivers, following from mountain to sea (Luitel, 2066b). They used to pray river "Saraswati" not to be violating, flooding, and harmful and not to destroy people's property because Saraswati River had nature of flooding. They had directly felt because town Dwaraka was on beach of Saraswati River. Besides this, all 'Asramas' were made on river beach. People of Vedik civilization were conscious to make water resources clean and clear. In Srimadbhagvat Mahapuran book ten Lord Krishna had concealed the saris of Gopini as punishment of making water pollution by bathing nakedly in River Yamuna because polluting water resource was taken as big sin. Some rivers of Vedic civilization and present time are stated in Table 1.

Table 1: Rivers in Vedic period and present time

\begin{tabular}{|c|l|l|l|l|}
\hline S.N & $\begin{array}{c}\text { Rivers named in } \\
\text { Ricveda }\end{array}$ & $\begin{array}{c}\text { Sources of verses } \\
\text { from Ricveda }\end{array}$ & $\begin{array}{c}\text { Recent } \\
\text { name }\end{array}$ & \multicolumn{1}{|c|}{$\begin{array}{c}\text { Recent address, } \\
\text { country }\end{array}$} \\
\hline 1 & Kubha & $5|53| 9$ & Kabul & Afghanistan \\
\hline 2 & Krumu & $5|53| 9$ & Kurrum & Afghanistan \\
\hline 3 & Gomati & $10|75| 6$ & Gomati & India, Uttar Pradesh \\
\hline 4 & Sarayu & $10|64| 9$ & Siritoi & India \\
\hline 5 & Prayiyu & $8|1| 37$ & Bara & Pakistan \\
\hline 6 & $\begin{array}{l}\text { Yamuna } \\
\text { Anumati }\end{array}$ & $5|52| 17$, & Yamuna & India \\
\hline
\end{tabular}




\begin{tabular}{|r|l|l|l|l|}
\hline 7 & Ganga $\backslash$ Janhawi & $6|45| 31$ & Ganga & $\begin{array}{l}\text { India and } \\
\text { Bangladesh }\end{array}$ \\
\hline 8 & Sindhu & $8|12| 3,8|20| 24$ & Indus & China India and Pakistan \\
\hline 9 & Susoma & $8|7| 29$ & Sohan & Pakistan \\
\hline 10 & Vitasta & $10|75| 5$ & Jhulam & $\begin{array}{l}\text { Northern India, and } \\
\text { Eastern Pakistan }\end{array}$ \\
\hline 11 & Asikni & $8|20| 25$ & Chenab & India, and Pakistan \\
\hline 12 & Parusni & $8|75| 15$ & Ravi & $\begin{array}{l}\text { Northern India, and } \\
\text { Eastern Pakistan }\end{array}$ \\
\hline 13 & Vipas & $4|30| 11$ & Beas & $\begin{array}{l}\text { Northern India, } \\
\text { Himanchal Pradesh }\end{array}$ \\
\hline 14 & Saraswati & $2|89| 3,1|1| 11$, & Saraswati & India \\
\hline
\end{tabular}

Source: Pal, 2012

\section{Human environment interaction}

People of Vedic civilization were rooted by religious thinking. They used to take God as supreme power. They used to think that all living and nonliving beings are created by god and environment as representative of god. They had taken human environment relationship as relation with God. They took water as "Barundev" wind as "Vayudev" fire as "Agnidev" earth as "Prithvimata" Forest as "Home of God" and so on. They thought everything through religious perspective. They had discouraged deforestation not to destroy the home of god. They acted everything in the name of god for their wellbeing. The "Shanti Mantra" of Shuklayajurveda (36:17) preais natural entities like space sun earth water herbs vegetation to be calm, peaceful and sweet and not to be violating for joyful human life (Luitel, 2066a). All human activities of that period were run through deterministic approach. People of that phase took changing natural phenomena and violating them as great sin. Agriculture was major and important occupation for them. They took agriculture as Uttam trade as Madhyam and job as Adham. Barley and peddy were major crops at that time. Livestock farming was another famous human activity during Vedic civilization. Cow and horse are major domestic animals. Cow was worshipped as "Gaumata" and domesticated for milk which is very important for human health and horse was massively used for transportation directly and pulling chariot. During this Period territoriality was also developed as different kingdom. King was taken as powerful person of state and king used to protect state from enemies. 
Different states were ruled by different kings like, Mathura by 'Kamsaa' Ayodhya by 'Ram' Lanka by 'Rawana' Magadha by 'Jarasandha' and so on.

Place attachment is another salient feature and cultural practice of Vedic civilization. They are very conscious about their places. As we see naming system of Vaidic practice can find that name to the new born baby is provided by calculating the Date of birth time and place, and position of stars and planet at birth time. It means name given from "ABAKAHADACHAKRA" to new born baby represents the various things of place.

\section{Measurement system}

During Vedic period measurement system was very systematic and logical. People in Vaidic period used to use materials used in everyday life as measurement tools like sticks, rope etc. Measurements were made to increase knowledge and understanding of the world they live. Measurement science is the basis of modern science and technology and consequently of modern civilization. The most necessary measurement in every walk of everyday life is length.

The length of human body parts was the basis for length measuring. The popular choice for length measurement were length and width of fingers, hands, hand spans, thumbs, cubits and body spans. But because of considerable variation in length and width of body parts of different person a piece of wooden stick rope and other materials were used as unit of length was one of the great ideas for length measurement.

The unit of length in Vaidic civilization included 'Dhanush' 'Krosha' and 'Yojana'. In Skanda Purana's Sadachar Khanda it is told that the toilet must be hundred Dhanush far from human settlement. Similarly, in fifth book of Mahapuran Srimadbhagvat the area of Bharatbarsha is stated one lakh Yojana. One yojana equels to four krosh. For measuring length and distance Chanakya has mensioned two type of Dhanusha namely, Ordinary Dhanusha consting of 96 angula (fingers) and Garhaptya Dhanusha consisting of 108 angula (fingers) (Shrivastav, 2017). Such measurement tools are used to measure road distance and individual land holding (Luitel, 2066c). The series of length measurement unit is stated in Table 2. 
Table: 2: Measurement units of length

\begin{tabular}{|c|c|c|}
\hline S.N & Vedic unit & Match with present unit \\
\hline 1 & 8 Pramanu & $\begin{array}{l}1 \text { Rajahkana: dust particle coming from wheel of } \\
\text { chariot }\end{array}$ \\
\hline 2 & 8 Rajahkana & Liksha': Size of egg of lice \\
\hline 3 & 8 Likssha & 1 yookamadhya \\
\hline 4 & 8 Yookamadhya & 1 Yavamadhya \\
\hline 5 & 8 yavamadhya & $\begin{array}{l}1 \text { 'Angula': approximately the width of finger (2 } \\
\mathrm{cm}\end{array}$ \\
\hline 6 & 4 Angula & 1 Dhanugraha $(8 \mathrm{~cm})$ \\
\hline 7 & 2 Dhanugraha & 1 'Dhanusmusthi' $(16 \mathrm{~cm})$ \\
\hline 8 & 3 Dhanugraha & 1 Vitta $(24 \mathrm{~cm})$ \\
\hline 9 & 2 Vitta & 1 Hasta $(48 \mathrm{~cm})$ \\
\hline 10 & 4 Hasta & 1 Dhanush 0r Danda $(192 \mathrm{~cm})$ \\
\hline 11 & 10 Danda & 1 Rajju (19.2 m) \\
\hline 12 & 2 Rajju & 1 Paridesh(38.4 m) \\
\hline 13 & 100 Paridesh & 1 Krosh: approximately $3.84 \mathrm{~km}$ \\
\hline 14 & 4 Krosh & 1 Yojana 15.376 km \\
\hline
\end{tabular}

Source: Shrivastav, 2017

The unit Yojana was used differently in different case in Pauranik literature. The yojana is used to measure length and area.

\section{Time measurement}

Vedic time measurement system is oldest and scientific time measurement system. Vedic scriptures give us a wealth of information about different methods and techniques used in Vedic civilization for time measurement. This measurement system is not only complete but also very precise and accurate. The time measurement system in Vedic civilization is very excellent and it covers a range 
from micro second to trillions of years including the cycle of universe. A time-based activity involves a time scale based on some system of measurement. All systems of time measurement are based on the time of revolution or rotation of various celestial bodies including the moon and the sun. People of pre-Aryan days were keenly interested in knowing the motion of heavenly bodies to predict solar and lunar eclipses and lunar month etc. There are 12 months each consisting of two paksh (14 days) according to the orbiting of the moon around the earth. The actual number of days in a month may vary by a day according to the position of the moon and the sun.

In Vedic and Puranic texts describe a system of time measurement starting with the time taken for twinkling of an eye and going up to the age of the creator Brahma, based on the solar/human year. During Vedic period, Indians had separate names for much smaller time intervals. The terms for smallest time interval and its multiples are shown in Table 3.

Table 3: Measurement unit of time

\begin{tabular}{|l|l|l|}
\hline S.N & Vedic units & Match with present units \\
\hline 1 & 1 pramanu & $26.3 \mu \mathrm{s}($ micro second) \\
\hline 2 & 2 pramanu & 1 anu $=52.67 \mu \mathrm{s}$ \\
\hline 3 & 3 anu & 1 trisrenu $=158 \mu \mathrm{s}$ \\
\hline 4 & 3 trisrenu & 1 truti $=474 \mu \mathrm{s}$ \\
\hline 5 & 100 Truti & 1 Bedh $=47.4$ ms \\
\hline 6 & 3 Bedh & 1 Love $=0.1 \mathrm{~s}$ \\
\hline 7 & 3 Love & 1 Nimesh $=0.43 \mathrm{~s}$ \\
\hline 8 & 3 Nimesh & 5 Kshana $=1$ kashtha $6.4 \mathrm{~s}$ \\
\hline 9 & 15 Kashtha & 1 Laghu= 1 Nadika= 1 Ghadi= 24 Minutes $=60$ pals \\
\hline 10 & 2 Nadika & 1 Muhurta $=48$ Minutes \\
\hline 11 & 30 muhurta & 1 day and 1 night (24 hours $)$ \\
\hline
\end{tabular}




\begin{tabular}{|l|l|l|}
\hline 12 & 7 day and 7 night & 1 Saptaha (1 Week) \\
\hline 13 & 2 saptaha & 1 Paksha (Forth night) \\
\hline 14 & 2 Paksha & 1 Month \\
\hline 15 & 2 Month & 1 season \\
\hline 16 & 3 Season & 1 Ayan \\
\hline 17 & 2 Ayan & 1 Year (365 Days) \\
\hline 18 & 100 Years & 1 Shatabdi \\
\hline 19 & 10 Shatabdi & 1 sahasrabdi \\
\hline 20 & 432 Sahasrabdi & 1 kaliyuga (432000 Human Years) \\
\hline 21 & 2 Kaliyuga & 1 Dwaparayuga (864000 Human Years) \\
\hline 22 & 3 Kaliyuga & 1 Tretayuga (1296000 Human Years) \\
\hline 23 & 4 Kaliyuga & 1 satyayuga (1728000 Human Years) \\
\hline 24 & 10 Kaliyuga & 1 Mahayuga (4320000 Human Years) \\
\hline 25 & 1000 Mahayuga & $\begin{array}{l}\text { Kalpa (4320000000 Human Years) one day of } \\
\text { Brahma }\end{array}$ \\
\hline
\end{tabular}

Source: Shrivastav, 2017

\section{Conclusion}

This paper tries to deal with geographical explanation within Vedic and Pauranik literature. Obviously, there are so many geographic elements discussed in Vedic literature. In this paper physical and human dimension of geography are tried to include. Knowingly or unknowingly peoples of Vedic Civilization were practicing geography. In Vaidic civilization geographical understanding, human environment is seen through religious perspective. Continents and topographic unites are very strongly presented in Vedic literature. Climatic change variation weather and season are obviously presented in Vedas and Puranas. However, such type of scientific truth and facts are of Vedic literature are ignored and neglected. All Vedas and puranas 
are taken as only through religious perspective no other. Besides this it is concluded that Vedas and other Vvedic literatures are full of scientific knowledge of geography which is to be included in curriculum of universities for affective transformation of knowledge of Vedic geography.

\section{References}

Gita Press (2000) Shreevedavyasapranita Sreemadbhagavatmahapurana. Gorakhpur: Gita Press

Gita Press (2000) Skanda Purana. Gorakhpur: Gita Press

Luitel T.P. (Ed.) (2066a) Yajurved. Kathmandu: Vidyarthi Pustak Bhandar

Luitel T.P. (Ed.) (2066b) Rigved. Kathmandu: Vidyarthi Pustak Bhandar

Luitel T.P. (Ed.) (2066c) Kautlya Arthasastra. Kathmandu: Vidyarthi Pustak Bhandar

Pal T. (2012) Physical Geography during Vedic-Civilization: A Literature Survey. International Journal of Academic Research in Progressive Education and development, Vol 1 (1) 15-30

Roller D.W. (2010) Eratosthenes's Geography. Oxford: Princeton University Press

Shrivastava S. K. (2017). Measurement units of length mass and time in India through the ages. International Journal of Physical and Social Science. Vol 7 (5) 39-43. 